\title{
ANALYZING THE EXPERIENCES OF WOMEN PRINCIPALS IN PRIMARY SCHOOLS IN LIMPOPO PROVINCE, SOUTH AFRICA THROUGH SOCIAL JUSTICE THEORY
}

\author{
Shuti Steph Khumalo \\ University of South Africa, South Africa \\ E-mail: ekhumass@unisa.ac.za
}

\begin{abstract}
School leadership research has provided extensive empirical evidence which shows that women as school leaders face challenges on many fronts. The objective of this study was to provide insight regarding the challenges that female primary school principals face, in the Waterberg Education District, Limpopo Province, South Africa. These challenges were in respect of the perception of staff members towards women as school principals. This study was qualitative and interpretive in nature. The theory of social justice was used as a theoretical framework. Social justice theorists argue that social institutions have the responsibility to dispense justice, fairness, and equity. The researcher used semi-structured in-depth interviews to gain rich descriptive data on the experiences relating to the leadership roles of the principals. Findings indicate that female principals face challenges, such as insubordination by male staff members, frustrations of not progressing beyond the position of principalship and sexual harassment. This study is of great value as it extends the body of knowledge on the challenges that primary school women principals face in their leadership practices.
\end{abstract}

Key words: social justice, women principals, sexual harassment, primary schools, insubordination, self-esteem, self-image

\section{Introduction}

In South Africa, like other African countries, it is common that the appointment of male principals hinges on cultural and traditional paradigmatic tendencies, despite the fact women represent the majority of and the significant number of the teaching profession (Karamanidou \& Bush, 2017, United Nations Educational, Scientific and Cultural Organization, 2011). Prior to 1994, before democracy in South Africa, the majority of principals appointed in both primary and secondary schools were men. Post-apartheid South Africa, and in particular this $21^{\text {st }}$ century has seen an increase in the appointment of females in school leadership positions, particularly principals. This was made possible by the enactment of the new constitution of the Republic of South Africa, which promotes gender and equality. Chapter 2 of the Constitution (Republic of South Africa 1996), sections 9(2) and 9(3), argues that the state may not unfairly discriminate directly or indirectly against anyone on the grounds of race and gender. Gender inequality in South Africa is a scourge that faces many black women who aspire to leadership positions (Noge, 2014). Reluctance in appointing and affording women the same opportunities as male principals, happens despite the enactment of progressive legislative policy frameworks such as the South African Employment Equity Act 55 of 1998, which seeks to redress the gender imbalances on leadership positions in the public service (Republic of South Africa 1998a, Republic of South Africa, 1998b). This policy change advocated for the advancement of the 
Shuti Steph KHUMALO. Analyzing the experiences of women principals in primary schools in Limpopo province, South Africa through social justice theory

PROBLEMS

OF EDUCATION IN THE $21^{\text {st }}$ CENTURY Vol. 79 , No. 1,2021

48

previously marginalized people, including women. The views expressed in these acts are indicated as follows:

No person may unfairly discriminate, directly or indirectly in the workplace by eliminating against an employee, in any employment policy or practice, on one or more grounds, including race, gender, sex, pregnancy, marital status, ... family responsibility" (Republic of South Africa, 1998a). The purpose of the Act is to achieve equity in the workplace, by promoting equal opportunity and fair treatment in employment through the elimination of unfair discrimination; and implementing affirmative action measures to redress the disadvantages in employment experienced by designated groups, to ensure their equitable representation in all occupational categories and levels in the workforce (Republic of South Africa, 1998b).

Women face challenges not only in their work environments, but also the roles that they play in their families and homes make matters worse. This is because women play critical and leading roles in their families, such as cooking and taking care of children. These family responsibilities are an added burden on women, and it is worse for women as principals. In addition to family-related burdens that women who occupy principalship position grapple with, there are also personality issues such as self-image and self-esteem. These attributes of selfconcept, self-image and self-esteem are fundamental in leadership because Soufi et al. (2011) are of the view that unstable self-esteem reflects fragile and vulnerable feelings. Coetzer (2004) claimed that if managers do not trust themselves, they will not be able to get along with others. The author further believes that many individuals in leadership positions experience major problems with inferiority complexes, constantly trying to prove themselves at all costs. Weeks (1998) postulated that stereotypical beliefs such as women's inability to be competitive, the inability to be decisive, and the inability to be emotionally stable continue to plague women managers. There is a strong belief by many in society that women are unable to control their tempers and are known for throwing tantrums.

Women as school managers need to develop an attitude that is able to withstand any form of challenges in the workplace. They have to have positive self-esteem and believe in themselves that they are capable of managing and leading, despite the challenges they face. Believing in oneself is fundamental, particularly in leadership and ample evidence in the form of literature indicates that high self-esteem correlates with desirable outcomes (Baumeister \& Vohs, 2018). Also, self-efficacy is critical in a school leadership position, as it is concerned with the competence that a person expects to display in challenging situations (Geijsel et al, 2009). It is also critical that women as school managers demonstrate evidence of effectiveness. This is important as Bandura (1986) posited that people who see themselves as efficacious are able to survive in situations that appear challenging. The issue of culture also finds itself in the workspace and is used by men to dominate women. In view of these assertions, Msuya (2017) argued that gender-related cultural practices, particularly in Africa, are harmful to women. Sahin (2018, p. 45) suggests that "because of cultural and historical stereotypes, there are prejudices among the members of societies that women cannot exhibit leadership behaviour compared to men." The school as an organisation is not excluded from cultural interferences because members of the school (teachers) come from communities which are culture bound. So, men who believe that they cannot be led by women will try to resist such leadership even in schools.

Women also suffer from the scourge of sexual harassment. The implications of sexual harassment have far-reaching effects on the organisational outcomes and particularly, the negative implications on the performance of victims (Thakur \& Paul, 2017, p. 35). It threatens the victims and impacts on their behaviour and their general productivity; it is also a hostile and unwanted practice and it threatens the target's well-being (Xin et al, 2018). These views are consistent with those of Mclaughlin et al. (2017) who posited that the majority of women experience sexual harassment at some point in their careers. The rationale for this study was 
to explore the dehumanising and unjust practices that black women principals face in primary

schools in South Africa. This research is significant because even though women in leadership is a widely and internationally researched area (Celikten, 2007), there is little empirical work on the challenges, issues and complexities that black women principals face, particularly in primary schools (Meryl, 2016).

\section{Research Problem}

There is a plethora of empirical evidence, both nationally and internationally that suggests that women face a myriad of challenges in educational settings (Coleman, et al, 2006; Mnisi, 2015; Moorosi, 2010). These studies demonstrate that women who ascend to positions of leadership face a number of challenges (Sperandio \& Kagoda 2008; Sperandio \& Kagoda 2010; Coleman, 2006; Coleman, 2012; \& Robinson et al, 2017). Amongst others, these stereotypes include the following: men are meant to lead and women to follow, men work well under pressure and are stronger, men are more reliable and more intelligent than women, men work harder than women, men should always be respected by women, that women who assert themselves do not get married, that women's special place is in the kitchen, that to be assertive is to be unfeminine, that successful women end up in divorce and that the family suffers if the women concentrate on their careers (Chen et al, 2012; Chisholm, 2017; Mnisi, 2015, Republic of South Africa, 2004). These challenges are not necessarily different from the women primary school principals, particularly for Black principals, in South Africa. The representation of women as principals in South African schools, particularly black women still remains a challenge as compared to men.

\section{Research Aim}

Flowing from the research problem stated above, the present study explores the challenges that are experienced by Black women principals in primary schools, from a particular area in South Africa. This was conducted through exploring the views of the participants of the study. For that reason, the main research question pursued in the study is: What are the pertinent challenges which women as primary school principals experience in the selected case in South Africa?

\section{Theory Underpinning the Study}

This study is undergirded by the theory of social justice. This theory of social justice is pertinent to the discipline of education, because it assists in exploring practices that are unfair and unjust. Maquire (2019) is of the view that social justice and education have a relationship. Rawls (1971) advocated for the theory of justice and identified a number of principles that define his understanding of justice. In this study, it can be argued that when women as school principals experience unfair and unjust treatment from their subordinates particularly men, this is a representation of unjust and dehumanising practices towards them. It can also be argued that cultural tendencies that purport to discriminate against women as principals on the basis of their femininity promote social injustice and erode the principle of equal opportunities for all. It is unfair for male teachers to behave negatively against women school managers because everyone has the right to promotion and the right to be respected. It is critical to note that fairness should be on the basis of competence and not just on the basis of femaleness, and therefore the appointment of women into the positions of principalship should be earned on the basis of competence, and not just on the basis of gender. 
Shuti Steph KHUMALO. Analyzing the experiences of women principals in primary schools in Limpopo province, South Africa through social justice theory

PROBLEMS

OF EDUCATION

IN THE $21^{\text {st }}$ CENTURY

Vol. 79, No. 1, 2021

Rawls (1971) sees the school as an example of social intuitions of the state. Drawing from this assertion, the researcher argues in this article that because the school serves as a basic structure of society, the fundamental rights of women as principals have to be respected. Unfair and unjust treatment of women as principals in their leadership roles perpetuates unfair and unjust treatment, which can be viewed as social injustice. Martin (1999) is of the view that theories of social justice offer acceptable mechanisms that can be used to regulate social arrangements in the fairest way for the benefit of all. Rawls (1971) (....) further contends that the principles of social justice provide a way of assigning rights and duties in the basic institutions of society, including primary schools. For example, women also have the right to occupy promotional positions, as principals and these should not be a privilege of men. Sensoy and DiAngelo (2017) strongly believe that all people are part of society and should not be valued unequally.

\section{Research Methodology}

\section{General Background}

For the researcher to explore the challenges that Black women as primary school principals face, the qualitative approach within an interpretive paradigm was employed. McMillan and Schumacher (2006, p. 43) are of the view that qualitative studies are helpful when the researcher wants to have an understanding of a human phenomenon. The researcher was able to collect data in the form of words through the description and explanations from the information of rich participants. This approach is affirmed by Mouton (2016, p.130) who noted that in qualitative inquiry, the researcher seeks to comprehend individuals in terms of their own interpretation of their world.

\section{Sample Selection}

Cohen et al. (2005) maintained that the quality of a piece of research not only stands by the appropriateness of methodology and instrumentation, but also by the suitability of the sampling strategy that has to be adopted. The researcher interviewed ten black women who are principals in primary schools in the Waterberg District Education (Limpopo Province) in South Africa. The ten principals from ten schools were selected from a population of 25 primary schools in the district indicated. The criteria for selection were women who are Black in terms of the definition of the race classification in South Africa, which means that they should not be white, coloured or Indian. In addition, participants were to have a minimum of five years as a principal. Further, the schools which they managed should have a staff complement of not less than 15 teachers drawing, from a mix of both male and female staff members. Geographically, schools were selected from a mix of rural, urban, formal, and informal settlements. Finally, the schools should be state schools and not private entities. They were asked to volunteer to participate in the study.

\section{Instrumentation and Procedures}

Data collection is at the heart of the research process (Phelps et al, 2007). The choice of data collection strategies is vital in the research process. Maree (2003) contends that a farreaching decision a researcher has to make is the way in which the data will be collected. The inappropriate choice of data collection techniques invalidates and makes the research outcomes unreliable. The semi-structured interviews were conducted with ten principals. The researcher used the semi-structured interviews because individual interviews are focused and 
enable the researcher to explore and unearth the pertinent challenges women as primary school principals face. During the interviews, field notes were recorded and through the permission of interviewees, the interview proceedings were recorded. The researcher allowed the use of English as a language of communication, but where possible, participants were allowed to switch to Sepedi, which is the predominant language in the region. The responses were translated into English, to make analysis of data easier for the researcher.

\section{Data Analysis}

Paton (2016) described data analysis as a very long and logical process of organizing, structuring and making sense of the vast amount of data collected by the researcher. The approach of data analysis was inductive which is described by Marshall and Rossman (2005, p.159) as discovering patterns, themes and categories in one's data. Thematic data analysis was used to analyse the transcribed data. During the transcriptions of the interviews, extra care was taken to ensure that their views were not tampered with but presented verbatim. This research was interpretive and descriptive in approach and there was no intention to generalize the results. The views of the principals were used to construct rich and contextualised understanding of their experiences namely the pertinent challenges that women as primary school principals experienced. To ensure that the findings were trustworthy, the researcher spent adequate time during the interviews to make sure that principals provide data that is accurate and rich. The interviews were also characterised by probing and prompting. The researcher also ensured that interview questions were not ambiguous.

\section{Research Results}

The purpose of this study was to analyse the experiences of women school principals in primary schools in Limpopo South Africa. A number of themes emerged from the data as a result of rigorous analysis and synthesis and were presented thematically through the use of descriptive analysis. The research positionality never influenced the study and the researcher tried to be as unbiased as possible. The views of participants were captured verbatim. A number of critical themes that emerged were the following:

- Insubordination by male subordinates

- Self-Image, self-esteem and psychological capital

- Glass ceiling syndrome: Not beyond school leadership

- Sexual harassment tendencies and practices

\section{Insubordination by Male Subordinates}

The interview was opened by the first question in which principals were expected to indicate their views on the attitudes of staff members particularly teachers towards them. In responding to the question, the majority of the participants revealed that they had issues with staff members, particularly with male staff. The principals indicated that they had the responsibility of ensuring that schools operate as per the requirements of the Department of Basic Education. In doing that they have to issue instructions to teachers during the day to day running of the schools. It is during these moments that they experience resistance from some teachers in particular males. In confirming insubordination and resistance from male teachers, this principal expressed her views as follows: 
Shuti Steph KHUMALO. Analyzing the experiences of women principals in primary schools in Limpopo province, South Africa through social justice theory

PROBLEMS

OF EDUCATION

IN THE $21^{\text {st }}$ CENTURY Vol. 79, No. 1, 2021

52
"I was once challenged by a male teacher, he said that he cannot be controlled by

a woman according to his culture. The teacher was also influencing others to stand against me. But I must stress that despite these problems of refusing my leadership, I must just soldier on and ensure that the school performs as expected". Ja also, our own, I mean women staff members who side with males".

From these sentiments expressed by the participant, even though male teachers in particular have issues with principals, also some teachers who are women also defy and undermine them.

\section{Self-Image, Self-Esteem and Psychological Capital}

Data analyses indicate that the majority of principals demonstrated that they had selftrust and self-confidence. This is viewed as an attribute of positive psychological capital where women as principals demonstrate high self-efficacy, high self-esteem and self-trust.

"No, I do not see myself as incapable in my duties. I have demonstrated that by being nominated for national teacher awards. No, men like to portray themselves as senior, but I don't allow that. Yes, I believe in myself, Yes, the little knowledge that I have makes me self-confident".

This view demonstrates that participant contradicts some of the literature arguments that women do not trust themselves.

\section{Glass Ceiling Syndrome: Not Beyond School Leadership}

Every employee wishes for promotion, particularly when the person is competent. It is therefore important that those that are capable and wish to apply for more senior positions be afforded such opportunities. Amongst the views expressed by participants was that most senior positions beyond the position of principalship are occupied mostly by men. One principal moaned,

"You know, I have been in this position for more than 8 years and have proven that I can perform, my school have been leading in different categories, you can think of athletics, culture, and academic. Look at the certificates and the trophies displayed. This is evidence enough. But vacancies have been advertised for circuit management positions, I have been trying left, right and centre, not even shortlisted. This district is male dominated by senior management." In corroborating this finding, one principal bluntly indicated that "A senior manager who mostly chairs the selection and interview panel, represents a patriarchal system. He is just a symbol of male domination. You can hear when we have principals meeting the way he addresses female principals."

\section{Sexual Harassment Tendencies and Practices}

The relationship in a workplace should be that of a professional nature where all employees respect each other. Employees can demonstrate unwelcome behaviour towards their supervisors such as school principals. Sexual harassment is an unwelcome behaviour that women as principals contend with. This issue was very thorny and controversial to introduce to participants as a result of the age difference of some of the participants who happen to be older that the researcher. Some of the participants chose not to comment much on the issue and were stating general viewpoints. Only four were able to confirm that they experienced this type of harassment in their careers. The researcher gathered from the participants that sexual harassment is manifested in different forms and from different sources. They intimated that 
Shuti Steph KHUMALO. Analyzing the experiences of women principals in primary schools in Limpopo province, South Africa through social justice theory

PROBLEMS

OF EDUCATION

IN THE $21^{\text {st }}$ CENTURY

Vol. 79, No. 1, 2021

some of their male subordinates appeared very brave and demonstrated guts to even advance during relaxed engagements such as school closing parties or during school tours. One principal related her ordeal:

"It was during my journey to the district meeting with the circuit manager. I travelled with one of my male HODs who is older in age than me. We were using my car and I decided that he drives, which I usually do not do. I always drive myself, no matter what. Because we used one transport, he thought this was an opportunity to advance. He started sexual talk in the form of jokes and persisted. I was not comfortable and kept silent, but he kept the same conversation. I then indicated to him that I am not OK. He could see my facial expression, and for a moment he kept quiet and changed the topic."

Undoubtedly, the views expressed by this principal significantly demonstrated the existence of incidences of sexual harassment in primary schools meted against female principals by their male subordinates.

\section{Discussion}

Day in and day out principals have to ensure that the objectives of the school are achieved. They do so through communication and part of this involves the issuing out of instructions. Their instructions are either received positively or negatively by their subordinates. Sometimes subordinates, particularly males, choose to ignore and defy the instructions from their principal to perform certain duties. Rawls' theory promotes principles such as the right to hold office and to be provided with opportunities. Defying their instructions not to promote such principles, for instance, when the principal requests teachers to supervise learners after hours during sporting activities. In view of this scenario, culture dynamics plays a fundamental role between the female principal and subordinate relationships. This scenario contradicts Rawls (1971) fairness principle that seeks to promote treatment of individuals the same irrespective of their gender makeup. Some participants indicated that men flatly refuse to take orders from them because they believe that they cannot take orders from women. In view of participants' perceptions, they overwhelmingly reported that they are defied by most of their subordinates. Robin et al. (2011, p.476) confirm that "the social interactions in which people claim and grant leader identities do not occur ex nihilo but are shaped according to traditions and by culturally available ideologies". Practices of male domination constitute gender inequality and promote unjust practices (Walby, 1990; Noge, 2014).

These findings negate the views of Rawls (1971) who perceives fairness and equality in social institutions, as the pillars of social justice. Showing insubordination towards women principals they promote social injustice and unfairness. Martin (1999), in supporting this claim, notes that theories of social justice provide acceptable opportunities to regulate social arrangements and relationships in the fairest way, for the benefit of all.

Self-image and self-esteem are the necessary attributes in sustaining women in leadership and are fundamental in the survival of women Black principals. When women principals believe in themselves, this will build their self-esteem. Self-esteem can be defined as the set of positive or negative evaluations of individuals about their own self (Koruk, 2017). Wang, Sui, Luthans, Wang and $\mathrm{Wu}(2014)$ refer to these attributes as psychological capital that include components such as resilience, optimism, and self-efficacy and hope (McMurray et al, 2010). Data analyses indicate that the majority of women as principals show that they have self-confidence. The results indicate that participants believe in themselves and are not intimidated by the Black male subordinates. This is despite the efforts of male teachers who keep on trying to undermine them. The results are consistent with the views of Rani and Chaturvedula (2018) when they argued that individuals with positive psychological capital portray enthusiasm and are optimistic about what they are doing. 
Shuti Steph KHUMALO. Analyzing the experiences of women principals in primary schools in Limpopo province, South Africa through social justice theory

PROBLEMS

OF EDUCATION

IN THE $21^{\text {st }}$ CENTURY

Vol. 79 , No. 1,2021

Social justice creates conditions necessary for self-respect. When primary schools operate in conditions where social justice principles such as respect and honour are at the fore front, especially by subordinates both male and female staff members, women as principals will also respect themselves. Self-respect is a social justice virtue. The perception of this participant demonstrates that there are female principals, who are able to stand for themselves and enforce the basic principles of social justice, namely equal basic rights and equality of opportunity. This occurs despite the hostile environments in which female principals find themselves in. The finding indicates that female principals do not need policy or legislation to stand for them, but instead they have to be in the frontline of their battles. This finding negates the assumption that females do not believe in themselves and thus cannot make good leadership. Drawing from this case, it can be argued that female principals are self-confident, self-esteemed and possess positive psychological capital.

The other critical theme that emerged from data is the glass ceiling syndrome. This has to do with upward mobility, particularly for those who work very hard and deserve promotion. Principals expressed dissatisfaction about their career upwards movement and indicated that they also aim to move upwards in their careers, some aiming to be future circuit managers, district managers, departmental superintendents and any other position above what they currently occupy. They do not refute the fact that there are those who are promoted but they lament the number of those who are promoted. Promoting women as principals enhances the principle of social justice because this comes with extra income and which promotes good quality of life.

Taking the views of these principals into consideration, it appears that women still face challenges with regard to them being promoted to senior management positions. The negative prejudices towards women have been at the forefront of their promotions. Osibanjo et al. (2013) refer to this phenomenon as the glass-ceiling syndrome. Karamanidou and Bush (2017) contend that studies on women leadership, indicate that gender has a substantial impact on women access and entry into senior leadership positions. At the same time, Chisholm-Burns et al. (2017) claim that despite the fact that women appear to be highly qualified and working in professional sectors, they are significantly often absent from senior leadership roles. These flawed perceptions that paint women in leadership position as incapable have been proven wrong by empirical evidence from research done in this area. The study conducted by Eckman (2004) focusing on women as high school principals found that they were capable in the same areas where men were capable. Adding to the debate of suppression of potential women in leadership positions, Karamanidou and Bush (2017) note that

"social barriers in the form of broader cultural expectations in terms of the sex role stereotypes, political, traditional and historical influences are even more problematic because they are so deeply rooted in the society and in the institutional cultures and are therefore not easy to eradicate".

Hallward and Stewart (2018) further posit that female leaders and their work within society outside of women's rights movements have rarely been publicly acknowledged or seen as equal to their male counterparts. These perceptions about women are flawed because the same society that recognises the critical roles that women play as leaders in their families and other sectors of community, view them as unable and weak when it comes to school leadership.

This position represents a designed cultural strategy by males to exclude women as principals from ascending the ladder of promotion beyond school leadership. These exclusionary measures are the expression of patriarchy and culture. This stance is exclusionary and socially unjust and negates the dictates of the theory of social justice. The theory of social justice from the Rawlsian perspective view states institutions such as schools as vehicles that 
should promote principles of fair and just practices. In this case, failing to promote women as principals beyond the position of school leadership due to their femaleness, negates social justice theories. Drawing from this finding, it can be argued and concluded that the practices meted against women as principals constitute inhumane and unjust behaviour and is a human rights issue.

The relationship in a workplace should be that of a brother-sister relationship where all employees respect each other. Employees can demonstrate unwelcome behaviour towards their supervisors such as school principals. Sexual harassment is an unwelcome behaviour that principals contend with on a daily basis. Social justice basic principles of human rights, respect and dignity are eroded when male subordinates harass female principals (Rawls, 1971). The position of such male teachers is a grave violation of the rights of women, which is rife in most South African public institutions. These unwelcome behaviours are displayed by male teachers who use their masculinity to advance their wishes to female principals. This behaviour constitutes sexual harassment and can be manifested in different forms. Some of these behaviours are salient and subtle and difficult to identify. When women who occupy principalship positions respect their black male subordinates, this is sometimes mistaken to be a weakness or at times interpreted as an opportunity to suggest sexual advances. Male teachers sexually harass their women principals through ways such as a request for a date, or sex-oriented comments or jokes. This happens despite some of the female principals being married or not.

Harris et al. (2017, p. 28) state that sexual harassment was originally defined as "deliberate or repeated unsolicited verbal comments, gestures, or physical contact of a sexual nature which are unwelcome". Not only do women as principals experience power domination from those who occupy senior positions, but from the subordinates they supervise.

Some of the participants interviewed implied that sexual harassment practices are common. Undoubtedly, the views expressed by the participants significantly demonstrate the existence of incidences of sexual harassment in primary schools meted against principals by their male subordinates. This finding indicates that sexual harassment is entrenched in schools. Confirming this view, Mclaughlin et al. (2017) discovered that the majority of women experience sexual harassment at some point in their careers. Similarly, Quick and McFadyen (2017) and Buchanana et al. $(2018$, p. 2) argue that the degree of sexual harassment in the workplace has reached alarming proportions that resulted in a number of organisations developing policies that seek to protect women who are victimised.

It is also worth stating that some of participants indicated sexual harassment is also meted against them by senior managers such as circuit managers and district directors. This confirms the view of the Department of Education (2004) indicating that sexual harassment also involves the abuse of power by senior employees as they wield some authority over the subordinates demanding sexual favours from subordinates to secure their jobs or be promoted or enjoy favourable working conditions. When women as principals are sexually harassed, these practices are unfair and unjust to the victims and serves as a perpetuation of social injustice. It is an infiltration of the rights of principals' human dignity. Human dignity is the foundation of social justice (Hibbert, 2017). Taking the findings on the views of the participants on sexual harassment into consideration and arguing it from the Rawlsian perspective of social justice, it can be concluded that the practices of senior members and subordinates on women as principals are exposed to dehumanising and unjust practices that constitute social injustice.

\section{Conclusions and Recommendations}

This study explored the challenges women principals in primary schools in South Africa face. Empirical evidence significantly found that women are confronted with challenges from many fronts. The majority of participants confirmed what literature exposed regarding women 
Shuti Steph KHUMALO. Analyzing the experiences of women principals in primary schools in Limpopo province, South Africa through social justice theory

PROBLEMS

OF EDUCATION IN THE $21^{\text {st }}$ CENTURY Vol. 79, No. 1, 2021

leadership. The views of the majority of participants confirmed that culture is used by male to colleagues to undermine their leadership. The study also found that women do not have adequate opportunities like men in terms of promotions beyond the office of the principal. Further, it was found that incidences of sexual harassment are evidenced by male counterparts' behaviour in the workplace and during school outings. Self-esteem of the participants was one of the dimensions that was critical in the study and it was found that the majority, if not all, pointed out that they believed in themselves despite the attitudes of their colleagues. The results of this study are significant because it focuses on the unjust and dehumanising lived experiences of black female principals in primary schools. The theory of social justice was used as a theoretical framework and it can be argued that primary school female principals experience unfair, unequal, and unjust challenges. Drawing from this assertion, this article concludes that social injustices are perpetuated against female primary school principals, and these practices negate the fundamental principles of social justice.

This research proposes simple but practical strategies that the Department of Basic Education, school and the school governing bodies could do to improve the situation. This study recommends that an aggressive advocacy and a strategy be developed with an intention to address prejudices against female school leadership in general, but particularly for Black female school principals. This strategy should be funded and be driven by the Department of Basic Education in collaboration with all stakeholders including the school governing body and trade unions representing teachers. It is also suggested that despite the challenges that female principals face, female school leaders who have been successful despite these barriers be drawn in as champions of these strategic campaign. This study was of limited scope and given the discovery of the challenges that female primary school principals face, it is recommended that future research on this area be extended to other primary schools and secondary schools.

\section{References}

Ademiluka, S. O. (2018). Patriarchy and women abuse: Perspectives from ancient Israel and Africa. Old Testament Essays, 31(2), 339-362. https://dx.doi.org/10.17159/2312-3621/2018/v31n2a5

Bandura, A. (1986). Fearful expectations and avoidant actions as coeffects of perceived selfinefficacy. American Psychologist, 41(12), 1389-1391. https://doi.org/10.1037/0003066X.41.12.1389

Baumeister, R. F., \& Vohs, K. D. (2018). Revisiting our reappraisal of the (surprisingly few) Benefits of high self-esteem. Perspectives on Psychological Science, 13(2), 137-140. https://doi.org/10.1177/1745691617701185

Buchanana, N. T, Settles, I. H, Wu, I. H. C., \& Hayashino, D. S. (2018). Sexual harassment, racial harassment and well-being among Asian American women: An intersectional approach. Women \&Therapy, 41(3-4), 1-20. https://doi.org/10.1080/02703149.2018.1425030

Celikten, M. (2007). A perspective on women principals in Turkey. International Journal of Leadership in Education, 8(3), 207-221. https://doi.org/10.1080/13603120500041835

Chen, A, Doherty, N., \& Vinnicombe, S. (2012). Developing women's career competencies through an emba. Gender in Management: An International Journal, 27(4), 232-248. https://doi.org/10.1108/17542411211244786

Coetzer, L. J. M. (2004). Management of educational institutions study guide. Ithuthuko Investment Publishing.

Chisholm, L. (2017). Gender and leadership in South African educational administration. Gender and Education, 13(4), 387-399. https://doi.org/10.1080/09540250120081742

Chisholm-Burns, M. A., Spivey, C. A., Hagemann, T., \& Josephson, M. A. (2017). Women in leadership and the bewildering glass ceiling. American Journal of Health-System Pharmacy, 74(5), 312-324. https://doi.org/10.2146/ajhp160930

Cohen, L., Manion, L., \& Morrison, K. 2005. Research methods in education. (5 ${ }^{\text {th }}$ ed). Routledge Farmer.

Coleman, M. (2012). Leadership and diversity. Educational Management Administration \& Leadership, 40(5), 592-609. 
Shuti Steph KHUMALO. Analyzing the experiences of women principals in primary schools in Limpopo province, South Africa through social justice theory

Coleman, S. (2006). The management style of female head teachers. Journal of Educational Administration, 24(2), 78-190. https://doi.org/10.1177\%2F0263211X96242005

Eagly, A. H., \& Carli, L. L. (2003). The female leadership advantage: An evaluation of the evidence. The Leadership Quarterly, 14(6), 807-834. https://doi.org/10.1016/j.leaqua.2003.09.004

Eckman, E. (2004). Similarities and differences in role conflict, role commitment, and job satisfaction for female and male high school principals, Educational Administration Quarterly, 40(3), 366-387. https://doi.org/10.1177\%2F0013161X03257835

Ely, R. J., Ibarra, H., \& Kolb, D. M. (2011). Taking gender into account: Theory and design for women's leadership development programs. Academy of Management Learning \& Education, 10(3), 474493. https://doi.org/10.5465/amle.2010.0046

Geijsel, F. P., Sleegers, P. J, Stoel, R. D., \& Krüger Pub Caret, M. L. (2009). The effect of teacher psychological and school organizational and leadership factors on teachers' professional learning in Dutch schools. The Elementary School Journal, 109(4), 406-427. https://doi.org/10.1086/593940

Gerwitz, S., Ball, S. J., \& Rowe, R. (1995). Markets, choice and equity in education. Open University Press

Carr, A. 2006. The handbook of child and adolescent clinical psychology: A conceptual approach (2nd ed.). Routledge.

Hallward, M., \& Stewart, C. (2018). Challenges and opportunities facing successful women in Morocco. Journal of North African Studies, 23(5), 1-25. https://doi.org/10.1080/13629387.2017.1422980

Harris, R. J., McDonald, D. P., \& Sparks, C. S. (2017). Sexual harassment in the military: Individual experiences, demographics, and organizational contexts, Armed Forces \& Society, 44(1), $25-43$. https://doi.org/10.1177\%2F0095327X16687069

Hibbert, N. (2017). Human rights and social justice. Laws, 6(2), 7.

Karamanidou, M., \& Bush, T., (2017). Women primary school principals in Cyprus: Barriers and facilitators to progression. ISEA, 45(1), 70-86.

Kessler, M. (2014). Female leaders in the 21st century in A masculine World. Koers - Bulletin for Christian Scholarship, 79(2), 1-7. http://dx.doi.org/10.4102/KOERS.V79I2.2117

Körük, S. (2017) The effect of self-esteem on student achievement. In: Karadag E. (Eds), The factors effecting student achievement. Springer, Cham. https://doi.org/10.1007/978-3-319-56083-0_15

Maree, G. J. 2003. Introduction to quantitative research. University of Pretoria.

Martin, J. (1999). Social justice, educational policy and the role of parents: A question of choice or voice? The Journal of Education and Social Justice, (1), 48-61. https://doi.org/10.1080/00220620701342395

Meryl, M. Y. (2016). Challenges faced by women primary school principals from the ZF Mgcawu district of the Northern Cape Province, [Unpublished Masters Dissertation], University of Free State.

Mclaughlin, H, Uggen, C., \& Blackstone, A. (2017). The economic and career effects of sexual harassment on working women. Gender and Society, 31(3), 333-358. https://doi.org/10.1177\%2F0891243217704631

McMillan, J. H., \& Schumacher, S. (2001). Research in education: A conceptual introduction (5 ${ }^{\text {th }}$ ed). Longman Publishers.

McMillian, J. H., \& Schumacher, S. (2006). Research in education: A conceptual introduction (6 ${ }^{\text {th }}$ ed). Harper.

McMurray, A. J., Pirola-Merlo, A., Sarros, J. C., \& Islam, M. M. (2010). Leadership, climate, psychological capital, commitment, and wellbeing: In a non-profit organization. Leadership \& Organization Development Journal, 31(5), 436-457. https://doi.org/10.1108/01437731011056452

Maquire, M. (2019). Equality and justice in education policy. Journal of Education Policy, 34(3), 299301 https://doi.org/10.1080/02680939.2019.1591709

Moorosi, P. (2010). South African female principals' career paths: Understanding the gender gap in secondary school management. Educational Management Administration \& Leadership, 38(5), 547-562. https://doi.org/10.1177\%2F1741143210373741

Mouton, J. (2016). How to succeed in your master's and doctoral studies. South African guide and resource book. Van Schaik.

M'mbaha, J. M., \& Chepyator-Thomson, J. R. (2018). Factors influencing career paths and progress of Kenyan women in sport leadership. Qualitative Research in Sport, Exercise and Health, 11(3), 1-18. https://doi.org/10.1080/2159676X.2018.1446042 
Shuti Steph KHUMALO. Analyzing the experiences of women principals in primary schools in Limpopo province, South Africa through social justice theory

PROBLEMS

OF EDUCATION IN THE $21^{\text {st }}$ CENTURY Vol. 79, No. 1, 2021

Mnisi, C. T. (2015). Female primary school leadership in the Bohlabela District of Mpumalanga: Challenges and strategies. Med Dissertation, Pretoria, University of South Africa.

Msuya, N. H (2017). Tradition and culture in Africa: Practices that facilitate trafficking of women and children, dignity. A Journal on Sexual Exploitation and Violence, 2(1), 1-36. https://doi.org/10.23860/dignity.2017.02.01.03

Noge, M. T. (2014). Evaluating patriarchy and gender inequality in an era of democracy: A Case of South Africa (1994-2012 [Masters Dissertation]. North West University.

Osibanjo, A. O., Iyiola, O. O., \& Adeniji, A. A. (2013). Glass-ceiling and female career advancement: A study of the Nigeria Police. Anvesha, 6(1), 49-59.

Patton, M. Q. 2015. Qualitative research and evaluation methods. ( $\left.3^{\text {rd }} \mathrm{ed}\right)$. Sage.

Phelps, R., Fisher, K., \& Ellis, A. (2007). Organizing and managing your research. A practical guide for postgraduates. Sage.

Pullen, A., \& Vachhani, S. J. (2018). Examining the politics of gendered difference in feminine leadership: The absence of 'female masculinity'. In Inclusive Leadership (pp. 125-149). Palgrave Macmillan, Cham. https://doi.org/10.1007/978-3-319-60666-8-6

Quick, J. C., \& McFadyen, M. (2017). Sexual harassment: Have we made any progress? Journal of Occupational Health Psychology, 22(3), 286. https://doi.org/10.1037/ocp0000054

Rani, E. K., \& Chaturvedula, S. (2018). Psychological capital: Gender differences and its relationship with job involvement. Defence Life Science Journal, 3(4), 383-387. https://doi.org/10.14429/dlsj.3.13675

Rawls, J. (1971). A theory of justice. (Revised edition). The Belknap Press of Havard University Press.

Republic of South Africa, (1996). RSA. The constitution of the Republic of South Africa, Act 108 of 1996. Government Printers.

Republic of South Africa, (1998a). Employment equity Act no 55 of 1998. Government Printers

Republic of South Africa, (1998b). Affirmative Action in the Public service, Government Gazette no.18800. Government Printers

Republic of South Africa, (2004). Department of Education. Women in and into management and leadership positions. Government Printers.

Republic of South Africa, (2017). Department of Basic Education, Annual report 2061/2017. Government Printers

Robin, J. E., Ibarra, H., \& Kolb, D. (2011). Taking gender into account: Theory and design for women leadership development programs. Insead, the business school for the world, faculty and research working paper, https://flora.insead.edu/fichiersti_wp/inseadwp2011/2011-69.pdf

Robinson, K., Shakeshaft, C., Grogan, M., \& Newcomb, W. S. (2017). Necessary but not sufficient: The continuing inequality between men and women in educational leadership, findings from the American Association of School Administrators Mid-Decade Survey. Frontiers in Education, (2), 12. https://doi.org/10.3389/feduc. 2017.00012

Sahin, A. (2018). Critical issues in Islamic education studies: Rethinking Islamic and Western liberal secular values of education. Religions, 9(11), 335. https://doi.org/10.3390/re19110335

Sensoy, O., \& DiAngelo, R. (2017). Is everyone really equal? An introduction to key concepts in social justice education. Teachers College Press.

Acemoglu, D., Johnson, S., Robinson, A. L., \& Yared, P. (2005). From education to democracy? American Economic Review, 95(2), 44-49. https://doi.org/10.1257/00028280577466991

Soufi, M., Gilaninia, S., \& Mousavian, S. J. (2011). Examine the relationship between self-esteem of women and lack of their appointment to organization senior posts. International Journal of Business and Social Science, 2(19), 287-292.

Sperandio, J., \& Kagoda, A. M. (2008). Advancing women into educational leadership in developing countries: The case of Uganda. Advancing Women in Leadership, 27, 1-14.

Sperandio, J., \& Kagoda, A. M. (2010). Women teachers' aspiration to school leadership in Uganda. International Journal of Educational Management, 24(1), 22-23. https://doi.org/10.1108/09513541011013024

Thakur, M. B., \& Paul, P. (2017). Sexual harassment in academic institutions: A conceptual review. Journal of Psychosocial Research, 12(1), 33-40.

United Nations Educational, Scientific and Cultural Organisation (2011). Women and the teaching profession, exploring the feminism debate, Retrieved from http://unesdoc.unesco.org/ images/0021/002122/212200e.pdf 
Shuti Steph KHUMALO. Analyzing the experiences of women principals in primary schools in Limpopo province, South Africa through social justice theory

PROBLEMS

OF EDUCATION

IN THE $21^{\text {st }}$ CENTURY

Vol. 79, No. 1, 2021

Walby, S. (1990). Theorizing Patriarchy. Basil Blackwell.

Wang, H., Sui, Y., Luthans, F., Wang, D., \& Wu, Y. (2014). Impact of authentic leadership on 59 performance: Role of followers' positive psychological capital and relational processes. Journal of Organizational Behavior, 35(1), 5-21. https://doi.org/10.1002/job.1850

Weeks, W. J. (1998). Factors Relative to the career advancement and seminar attendance of women managers. University Microfilms International.

Xin, J, Chen, S., Kwan, H. K., Chiu, R. C., \& Yim, F. H. (2018). Work family spill over and crossover effects of sexual harassment: The moderating role of work-home segmentation preference. Journal Business Ethics, 147(3), 619-629. https://doi.org/10.1007/s10551-015-2966-9

Received: July 24, 2020

Accepted: January 08, 2021

Cite as: Khumalo, S. S. (2021). Analyzing the experiences of women principals in primary schools in Limpopo province, South Africa through social justice theory. Problems of Education in the $21^{\text {st }}$ Century, 79(1), 47-59. https://doi.org/10.33225/pec/21.79.47

Shuti Steph Khumalo

Phd (Education Management and Leadership), Senior Lecturer, University of South Africa, I Preller Street Muckenick, Pretoria, Republic of South Africa.

E-mail: ekhumass@unisa.ac.za

ORCID: https://orcid.org/0000-0002-2977-2851 